\title{
Indoor Air Quality in Primary Schools
}

\author{
Maria do Carmo Freitas et al.* \\ Instituto Tecnológico e Nuclear (ITN), URSN, Sacavém, \\ Portugal
}

\section{Introduction}

Clean air is a basic requirement of life (World Health Organization, 2010). The Indoor Air Quality (IAQ) has been the object of several studies due to an increasing concern within the scientific community on the effects of indoor air quality upon health, especially as people tend to spend more time indoors than outdoors (Franck et al., 2011; Canha et al., 2010; WHO, 2010; Environmental Protection Agency, 2010; Saliba et al., 2009; Fraga et al., 2008; Fromme et al., 2007; Guo et al., 2004; Kosonen, 2004; Lee et al., 2002a; Lee et al., 2002b; Carrer et al., 2002; Lee et al., 2001; Li et al., 2001; Wilson \& Spengler, 1996; Allen \& Miguel, 1995; Jenkins et al., 1992; WHO, n.d.). The quality of air inside homes, offices, schools or other private and public buildings is an essential determinant of healthy life and people's well-being (WHO, 2010).

People can be exposed to contaminants by inhalation, ingestion and dermal contact. In the past, scientists have paid much attention to the study of exposure to outdoor air contaminants, because they have realised the seriousness of outdoor air pollution problems. However, each indoor microenvironment has unique characteristics, determined by the local outdoor air, specific building characteristics and indoor activities (Pegas et al, 2010). Indeed, hazardous substances are emitted from buildings, construction materials and indoor equipment or due to human activities indoors (WHO, 2010; Carrer et al., 2002).

Reports about buildings with air-related problems have received increasing attention since the 1970s (Spengler \& Sexton, 1983; Hodgson, 1992). In an indoor environment, dust on floors and other surfaces contains minerals, metals, fibres from textiles, paper, and insulation material, particles from tobacco smoke, including polycyclic aromatic compounds (PAH's). For this reason, the indoor environment is cleaned to maintain an acceptable level of perceived cleanliness, to prevent surface degradation, to control potential risk of infection from microorganisms, and to control dust exposure in general (Wolkoff et al., 1998). All of these pollutants could cause significant damage to health globally (WHO, 2010).

\footnotetext{
* Nuno Canha ${ }^{1}$, Maria Martinho ${ }^{2}$, Marina Almeida-Silva ${ }^{3}$, Susana Marta Almeida ${ }^{3}$, Priscilla Pegas ${ }^{4}$, Célia Alves ${ }^{4}$, Casimiro Pio ${ }^{4}$, Maria Trancoso ${ }^{5}$, Rita Sousa ${ }^{5}$, Filomena Mouro ${ }^{5}$, Teresa Contreiras ${ }^{6}$

${ }^{1}$ Instituto Tecnológico e Nuclear (ITN), URSN, Sacavém, Portugal

${ }^{2}$ United Nations, Department of Economic and Social Affairs, NY,USA

${ }^{3}$ Instituto Tecnológico e Nuclear (ITN), URSN, Sacavém,Portugal

${ }^{4}$ Universidade de Aveiro/ CESAM,Aveiro,Portugal

${ }^{5}$ Laboratório Nacional de Energia e Geologia / LAQ,Lisboa,Portugal

${ }^{6}$ Instituto Nacional de Saúde Dr Ricardo Jorge / ONSA,Lisboa,Portugal
} 
The IAQ in school buildings is expected to be a key role player in the assessment of the effects of the children personal exposure to air pollution as children spend at least a third of their time inside school buildings, that is, approximately seven or more hours a day in school (Almeida et al., 2010; EPA, 2010; Pegas et al., 2010; Wheeler et al., 2009; Ramachandran et al., 2005). Poor IAQ can affect scholarly performance and attendance (Daisey et al. 2003; Godoi et al. 2009). Hence, several studies about air quality in schools have recently been published (Goyal \& Khare, 2009; Tippayawong et al., 2009; Fraga et al., 2008; Fromme et al., 2007; Hwang et al., 2006). Environmental asthma triggers commonly found in school buildings include respiratory viruses; cockroaches and other pests; mold resulting from excess moisture in the building; dander from animals in the classroom; and dander brought on the clothing from animals at home. Second-hand smoke and dust mites are other known environmental asthma triggers found in schools. Children with asthma may be affected by other pollutants from sources inside schools, such as unvented stoves or heaters and common products including chemicals, cleaning agents, perfumes, pesticides and sprays.

Indoor Air Quality problems in schools may be even more serious than in other categories of buildings, due to higher occupant density and insufficient outside air supply, aggravated by frequent poor construction and/or maintenance of school buildings (Pegas et al., 2010). Schools are seen as particularly likely to have environmental deficiencies because chronic shortages of funding contribute to inadequate operation and maintenance of facilities (Mendell \& Heath, 2005). Previous studies showed the poor indoor environmental quality at schools may be explained by: (1) insufficient ventilation in schools, especially in winter, (2) infrequently and not thoroughly cleaned indoor surfaces, and (3) a large number of students in relation to room area and volume, with constant re-suspension of particles from room surfaces (Janssen et al., 1999).

Children constitute a sensitive group with higher risk than adults (Stranger et al., 2007a) because children are particularly vulnerable to pollutants due to their undeveloped airways (Stranger et al., 2007a; Mendell et al., 2005). Moreover, children have greater susceptibility to some environmental pollutants than adults, because they breathe higher volumes of air relative to their body weights and their tissues and organs are actively growing (Mendell \& Heath, 2005). The effects of air pollution on children have been growing (Khan et al., 2007) and one of the consequences is the increase of the prevalence of allergic rhinitis (ISAAC, 1998).

The chemical and microbiological parameters required by the Portuguese Legislation for IAQ monitoring purposes are: carbon dioxide $\left(\mathrm{CO}_{2}\right)$, carbon monoxide $(\mathrm{CO})$, ozone $\left(\mathrm{O}_{3}\right)$, formaldehyde (HCHO), volatiles organic compound (VOCs), bacteria and fungi (DL n. ${ }^{\circ}$ 79/2006). Some of these parameters will be studied below.

\subsection{Particulate matter}

Particulate matter (PM) may be divided into two broad classes depending upon the manner by which it is introduced into atmosphere. A primary component consists of those particles released directly from their source, while a secondary component consists of those particles created in the atmosphere via chemical reactions between pollutants that were originally emitted as gases (Gilli et al., 2007; Schlesinger \& Cassie, 2003; Mysliwiec \& Kleeman, 2002). Indoor particle concentration depends on penetration of outdoor particles into the indoor environment and on the intensity of indoor aerosol sources (Estoková et al., 2010; Franck et al., 2011; Estoková et al., 2010). The number and behavior of inhabitants and the amount of indoor contamination sources determine temporal and spatial variations of indoor aerosol distribution. In addition, wet processes as cleaning, washing and drying increase relative 
humidity which can lead to variations in particle size distribution (Estoková et al., 2010). The particles can also vary in their chemical composition (Karthikeyan \& Balasubramanian, 2006).

For legislation purposes, PM is defined as "inhalable" if its aerodynamic diameter is below $10 \mu \mathrm{m}\left(\mathrm{PM}_{10}\right)$, but there is continuing debate whether the adverse health effects of PM are associated more with small particles or not (Grigg, 2009). Inhalation of particulate material may cause prejudicial human health effects either in the short or long terms (Allen \& Miguel, 1995).

Many epidemiological studies found correlations between exposure to PM (or PM components) and adverse health effects (Franck, et al., 2011; Estoková, et al., 2010; Tippayawong et al., 2009; Fang et al., 2006; Wilson \& Spengler, 1996). Hazardous influence of particles is related to their penetrations and deposition into human respiratory system. Nevertheless, there is no clear agreement as to a biologically plausible mechanism, which can explain the acute mortality/morbidity, associated with PM exposure. In addition there is no consensus as to which components of PM are responsible for the excess mortality and morbidity (González-Flecha, 2004).

PM sources typically include smoking and cooking. While the school environment lacks these typical indoor PM sources, there is growing evidence of high concentrations of PM in classrooms (Stranger et al., 2007b; Janssen et al., 2001).

\subsubsection{Chemical elements and water-soluble lons}

Due to inhalation exposure, the chemical composition of the particulate matter can cause toxic health effects on humans. In particular, the presence of metal substances is considered to be a significant factor of health risk. Although elemental components constitute only a small portion by mass of $\mathrm{PM}$, some trace elements (e.g. $\mathrm{Pb}, \mathrm{As}, \mathrm{Se}, \mathrm{Cd}, \mathrm{Hg}$, etc.) may pose a serious threat to human health, causing inflammation or DNA damage, and altering permeability by inducing production of oxygen species (OHd) in tissues (Health Effects Institute, 2002).

There have been numerous studies that have measured the concentrations of PM within indoor environments. In a study taken by the Department of Environmental Sciences, Environmental and Occupational Health Group, in the University of Wageningen in the Netherlands, with the objective to investigate the sources of high concentrations of $\mathrm{PM}_{10}$ particles in classrooms, they observed that the highest classroom/outdoor ratios were found for the elements from soils $\mathrm{Si}, \mathrm{Ca}$ and $\mathrm{Ti}$. The only measured elements that were not increased were $\mathrm{S}, \mathrm{Pb}, \mathrm{Br}$ and $\mathrm{Cl}$, which are dominated by non-crustal sources. For $\mathrm{S}, \mathrm{Br}$ and $\mathrm{Pb}$, which are generally associated with particles $<1 \mu \mathrm{m}$, significant correlations between classroom and outdoor concentrations and between two classrooms were found (Janssen et al., 1999).

The chemical composition of particulate matter is important to gain insights into sources (Karthikeyan \& Balasubramanian, 2006). Buildings can be considered to be small chemical reaction chambers embedded in the larger outdoor atmosphere with different surface to volume ratios, temperatures, and residence times, which interact with and are influenced by the outdoor (Lunden et al., 2003). Phase changes may also affect particle concentrations, and may be rapid with respect to residence times. Vapor absorption or reaction at the surfaces inside the residence may be important to the partitioning of semi-volatile constituents between the vapor and particle phases. A number of important aerosol chemical species are prime candidates for continued chemical interactions indoors, including organic carbon and ammonium nitrate (Lunden et al., 2003). Some of these chemicals were found indoors and can cause irritation of skin, respiratory system and eyes (Allen \& Miguel, 1995). Different studies have shown persuasive evidence linking higher indoor $\mathrm{NO}_{2}$ concentrations to 
reduced school attendance and low ventilation rates to reduced performance (Mendell et al., 2005; Kim et al., 2007).

\subsection{Volatile Organic Compounds and carbonyls}

In the scientific literature, two different emissions types of Volatile Organic Compounds (VOCs) are defined: primary and secondary. The primary emissions are free (non-bound) VOCs. These generally are low molecular weight VOCs. Secondary emissions are chemically or physically bound VOCs and several of these are emitted or formed by different processes under special chemical or physical conditions (Wolkoff, 1999). VOCs are easily released into indoor air and are recognized as the major air pollutants in the indoor air (Guo et al., 2004; Viegas \& Prista, 2010). One of the most important sources of VOCs are the consumer products, like wood, paint, food, cleaners, etc. Results from a study in dwellings suggest that indoor VOCs and formaldehyde may cause asthma-like symptoms (Norback et al., 1995).

Indoor air is a significant source of benzene exposure and inhalation is the main pathway of human exposure to this pollutant. Benzene is a genotoxic carcinogen in humans. There is no known exposure threshold for the risk of benzene exposure, so, it is expedient to reduce indoor exposure levels to as low as possible: no safe level of exposure can be recommended (WHO, 2010).

In schools, the most commonly measured pollutants in indoor air are formaldehyde, total VOCs, $\mathrm{CO}_{2}$ and bioaerosols (Bayer et al., 2000).

\section{Material and methods}

\subsection{Sampling site and schools description}

This study was carried out in Lisbon, which is the largest city of Portugal. Lisbon has a population of about half a million inhabitants in $84.8 \mathrm{~km}^{2}$ while the metropolitan area of $2870 \mathrm{~km}^{2}$ has around 2.8 million inhabitants (Almeida et al., 2010).

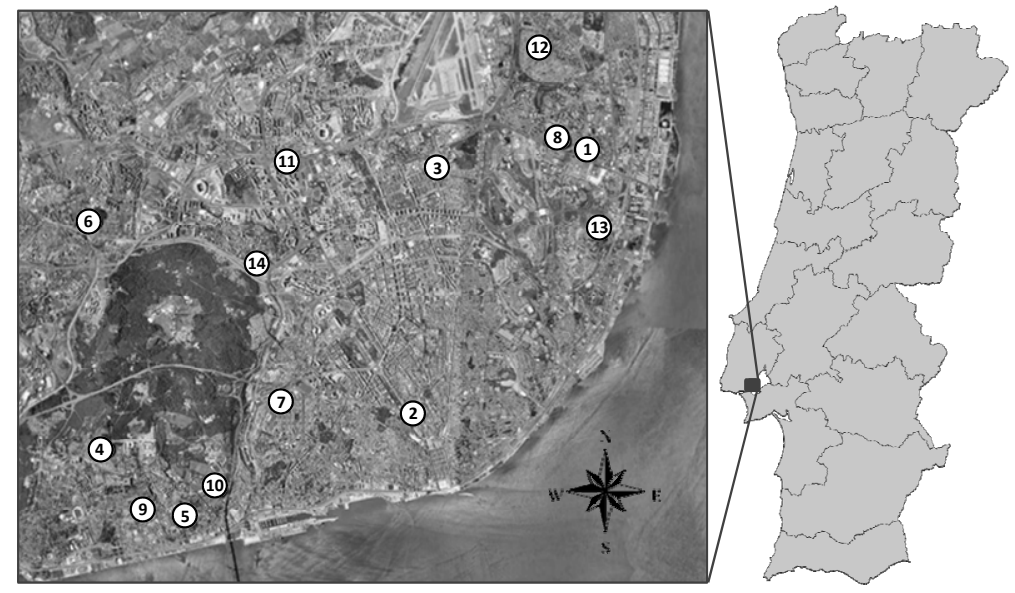

Fig. 1. Spatial distribution of the 14 primary schools in Lisbon, Portugal, studied in this work.

Data on the characteristics of classrooms and indoor air were collected in 14 primary schools in Lisbon. Figure 1 shows the location of these 14 primary schools. For each school, data 
were collected in two classrooms, named for reference purposes as classroom "a" and classroom " $\mathrm{b}$ ". The information concerning the classrooms characteristics is presented in Table 1. All schools have natural ventilation and there is no forced ventilation or air conditioning system in use (ventilation is done by opening doors and windows).

The data studied here is part of a larger study, which has been described and analysed in previous research (Almeida et al., 2011; Canha et al., 2010, 2011; Pegas et al., 2010, 2011a, 2011b).

\subsection{Sampling and chemical analysis}

Three campaigns for total particulate matter sampling were conducted: spring (May-June 2009, total of 34 days), autumn (October-December 2009, total of 62/68 days) and winter (January-March 2010, total of 76/78 days). Sampling of VOCs and carbonyls was performed in the same periods but only for 14 consecutive days within the studied season. Although there are results for all the campaigns and measured parameters, only the campaigns and measured parameters which have results for the two classrooms of all 14 schools were considered in this study. They are shortly described below. All the values of the parameters were normalized to the day.

\subsubsection{Mass of total particulate matter (TPM)}

Filters were passively exposed (Canha et al, 2011). A total of six 47-mm diameter Millipore (Isopore $^{\mathrm{TM}}$ ) polycarbonate filters were exposed in each classroom, distributed over a tray with an area of $25 \mathrm{~cm} \times 20 \mathrm{~cm}$, at $120-\mathrm{cm}$ high to approximate the breathing height of children inside the classrooms. Each filter was placed inside an uncovered plastic Petri dish. Filters with pore sizes of 0.4 and $0.8 \mu \mathrm{m}$ were used. The filter loads were measured by gravimetry with a $0.1 \mu \mathrm{g}$ sensitivity balance, in a controlled clean room (class 10,000) inside a 100 class clean hood. Filter mass before and after sampling was obtained as the average of three measurements, when observed variations were less than $5 \%$.

\subsubsection{Mass of chemical elements in TPM}

The exposed Millipore-polycarbonate filters and their corresponding blank filters were irradiated at the Portuguese Research Reactor (RPI-ITN; nominal power: $1 \mathrm{MW}$ ) for analyses by $\mathrm{k}_{0}$-INAA (Canha et al., 2010). Irradiation time was $5 \mathrm{~h}$ at a neutron flux density of $8 \times 10^{12}$ $\mathrm{cm}^{-2} \mathrm{~s}^{-1}$. Each sample was rolled up and put into an aluminium foil for irradiation, removed from the foil after irradiation and put in a polyethylene container for measurement. Samples were measured $7 \mathrm{~h}$ after 3-5 days and after 3-4 weeks, with an ORTEC ${ }^{\circledR}$ automatic sample changer, equipped with an ORTEC coaxial hyperpure germanium detector $(1.90 \mathrm{keV}$ resolution at $1.33 \mathrm{MeV} ; 30 \%$ relative efficiency). One Al- $0.1 \%$ Au alloy disc with a thickness of $125 \mu \mathrm{m}$ and a diameter of $0.5 \mathrm{~cm}$ was used as comparator for the $\mathrm{k}_{0}$-methodology, and irradiated concurrently with the samples. A total of 4 replicates were analyzed for each type of blank filter.

The chemical elements discussed in this study are gold $(\mathrm{Au})$, chromium $(\mathrm{Cr})$, potassium $(\mathrm{K})$, antimony (Sb), scandium (Sc), and zinc (Zn).

\subsubsection{Mass of water-soluble ions in TPM}

Exposed polycarbonate filters were used for the determination of water-soluble inorganic ions. For each classroom, a set of 2-4 filters were used together as a unique sample. All the polyethylene containers and other used material in the process were decontaminated and water soluble sodium and nitrate ions contents were previously determined to confirm free 
contamination status of the material. This step was highly crucial to avoid contaminations and biased results, due to the small mass of the samples. TPM on the samples was extracted with $25 \mathrm{~mL}$ of distilled deionized water by ultrasonic ( 30 minutes) and mechanical shaking (15 hours with 350 r.p.m.). Afterwards, the mixture was filtered using a syringe filter of porosity of $0.45 \mu \mathrm{m}$.

\begin{tabular}{|c|c|c|c|c|c|c|c|c|c|c|c|}
\hline School & Classroom & Floor level & $1 \begin{array}{c}\text { Students } \\
\text { per } \mathrm{m}^{3}\end{array}$ & \begin{tabular}{|c|}
$\mathrm{Nr}$ \\
Windows/ \\
doors \\
opened
\end{tabular} & $\begin{array}{c}\text { Type } \\
\text { of } \\
\text { board }\end{array}$ & $\begin{array}{c}\text { Floor } \\
\text { material }\end{array}$ & $\mid \begin{array}{c}\text { Ceiling } \\
\text { material }\end{array}$ & $\begin{array}{l}\text { Heating } \\
\text { device }\end{array}$ & $\begin{array}{l}\text { Dust on } \\
\text { surfaces }\end{array}$ & $\begin{array}{c}\mathrm{Nr} \\
\text { Cleaning } \\
\text { per day }\end{array}$ & $\begin{array}{l}\text { View from } \\
\text { the } \\
\text { classroom }\end{array}$ \\
\hline \multirow{2}{*}{1} & $\mathrm{a}$ & Ground & 0.1866 & 2 & Chalk & Brick & Slab & No & No & 1 & Street \\
\hline & $\mathrm{b}$ & Ground & 0.1778 & 2 & Chalk & Brick & Slab & No & No & 1 & Street \\
\hline \multirow{2}{*}{2} & $\mathrm{a}$ & Ground & 0.0922 & 1 & Chalk & Brick & Slab & Yes & Yes & 1 & Patio \\
\hline & $\mathrm{b}$ & Ground & 0.0922 & 3 & Chalk & Brick & Slab & Yes & Yes & 2 & Patio \\
\hline \multirow{2}{*}{3} & $\mathrm{a}$ & First & 0.2334 & 2 & Pen & Brick & Slab & Yes & Yes & 1 & Patio \\
\hline & $\mathrm{b}$ & First & 0.2826 & 0 & Chalk & Brick & Slab & Yes & Yes & 1 & Patio \\
\hline \multirow{2}{*}{4} & $\mathrm{a}$ & First & 0.1374 & 2 & Chalk & Wood & Slab & Yes & Yes & 1 & Street \\
\hline & $\mathrm{b}$ & First & 0.1522 & 1 & Chalk & Wood & Slab & Yes & Yes & 1 & Street \\
\hline \multirow{2}{*}{5} & $\mathrm{a}$ & First & 0.1352 & 3 & Chalk & Wood & Slab & Yes & Yes & 1 & Patio \\
\hline & $\mathrm{b}$ & First & 0.1128 & 3 & Chalk & Wood & Slab & Yes & Yes & 1 & Patio \\
\hline \multirow{2}{*}{6} & $\mathrm{a}$ & Ground & 0.1250 & 3 & Chalk & Brick & Slab & Yes & No & 2 & Patio \\
\hline & $\mathrm{b}$ & First & 0.1191 & 3 & Chalk & Brick & Slab & Yes & No & 2 & Patio \\
\hline \multirow{2}{*}{7} & $\mathrm{a}$ & First & 0.0892 & 1 & Chalk & Vinyl & Wood & No & Yes & 1 & Patio \\
\hline & $\mathrm{b}$ & Basement & 0.1126 & 0 & Chalk & Vinyl & Wood & No & Yes & 1 & Street \\
\hline \multirow{2}{*}{8} & $\mathrm{a}$ & First & 0.1221 & 2 & Chalk & Vinyl & Cork & No & Yes & 2 & Patio \\
\hline & $\mathrm{b}$ & First & 0.1221 & 2 & Chalk & Vinyl & Cork & No & Yes & 2 & Patio \\
\hline \multirow{2}{*}{9} & $\mathrm{a}$ & First & 0.1204 & 3 & Chalk & Brick & Slab & Yes & Yes & 1 & Patio \\
\hline & $\mathrm{b}$ & First & 0.1240 & 3 & Chalk & Wood & Slab & Yes & Yes & 1 & Patio \\
\hline \multirow{2}{*}{10} & $\mathrm{a}$ & First & 0.0923 & 3 & Chalk & Wood & False & Yes & Yes & 1 & Street \\
\hline & $\mathrm{b}$ & First & 0.1438 & 2 & Chalk & Wood & Slab & Yes & Yes & 1 & Patio \\
\hline \multirow{2}{*}{11} & $\mathrm{a}$ & Ground & 0.1302 & 3 & Chalk & Brick & Cork & Yes & Yes & 2 & Street \\
\hline & $\mathrm{b}$ & Ground & 0.1270 & 3 & Chalk & Brick & Cork & Yes & Yes & 2 & Street \\
\hline \multirow{2}{*}{12} & $\mathrm{a}$ & Ground & 0.1324 & 1 & Chalk & Vinyl & Slab & No & Yes & 2 & Street \\
\hline & $\mathrm{b}$ & First & 0.1129 & 1 & Pen & Vinyl & Slab & No & Yes & 2 & Street \\
\hline \multirow{2}{*}{13} & $\mathrm{a}$ & Ground & 0.1254 & 2 & Chalk & Brick & Slab & No & Yes & 1 & Patio \\
\hline & $\mathrm{b}$ & Ground & 0.1197 & 2 & Chalk & Brick & Slab & No & Yes & 1 & Patio \\
\hline \multirow{2}{*}{14} & $\mathrm{a}$ & First & 0.1315 & 2 & Chalk & Plastic & Slab & Yes & Yes & 1 & Patio \\
\hline & $\mathrm{b}$ & First & 0.1282 & 3 & Chalk & Vinyl & Slab & Yes & Yes & 1 & Patio \\
\hline
\end{tabular}

Table 1. Classrooms characteristics.

The aqueous extract was analyzed by chemical suppressed ion Chromatography (Chow and Watson, 1999) - for $\mathrm{Cl}^{-}, \mathrm{NO}_{3}^{-}, \mathrm{PO}_{4}^{3-}, \mathrm{F}-$ and $\mathrm{SO}_{4}{ }^{2-}-$ and Flame Atomic Absorption Spectroscopy - for $\mathrm{Ca}^{+}, \mathrm{Mg}^{2+}, \mathrm{Na}^{+}$and $\mathrm{K}^{+}$.

\subsubsection{VOCs \& carbonyls}

Volatile Organic Compounds and carbonyls were sampled in parallel using Radiello ${ }^{\circledR}$ diffusive passive tubes (cartridges codes 130 and 165, respectively) for 14 consecutive days in two replicates (Pegas et al., 2010, 2011a, 2011b). Samples were collected at a height of 
about $1.5 \mathrm{~m}$ above the classroom floor. The diffusive samplers were positioned at a distance that exceeded $1 \mathrm{~m}$ from any window or door.

\subsubsection{VOCs}

The VOC adsorbing cartridges consisted of $60 \mathrm{~mm}$ length stainless steel net cylinders, with 100 mesh grid opening and $5.8 \mathrm{~mm}$ diameter, packed with $530 \pm 30 \mathrm{mg}$ of activated charcoal with a particle size of 35-50 mesh. VOCs were extracted from the exposed samplers with 2 $\mathrm{ml}$ of carbon disulfide $\left(\mathrm{CS}_{2}\right)$ containing 2-fluorotoluene as an internal standard. The glass vials were shaken for approximately $30 \mathrm{~min}$. The analyses of the extracts were performed by gas chromatography coupled to a flame ionisation detector (GC/FID). The equipment was calibrated before and during the sample analyses by injecting four standard solutions of all compounds identified in $\mathrm{CS}_{2}$. The analytes in these four standard solutions were present in concentrations of $40 \mathrm{ng} \mu \mathrm{l}^{-1}, 20 \mathrm{ng} \mu \mathrm{l}^{-1}, 10 \mathrm{ng} \mu^{-1}$ and $5 \mathrm{ng} \mu \mathrm{l}^{-1}$. Depending on the analyte, the limit of detection (LOD $=3.3(\mathrm{~s} / \mathrm{S})$, where $\mathrm{s}$ is the STDEV of areas and $\mathrm{S}$ is the slope) ranged from 0.34 to $2.52 \mathrm{ng}^{\mu \mathrm{l}^{-1} \text {. }}$.

The analyzed VOCs discussed in this study are aliphatic hydrocarbons (2-methylpentane $A C$, n-hexane - AD, isooctane - AE, n-heptane - AF), aromatic hydrocarbons (benzene - AW, toluene - AY, ethylbenzene - AZ, m+p-xylene - BA, o-xylene - BC) and cyclohexane - BT.

\subsubsection{Carbonyls}

Carbonyls collected in cartridges filled with 2,4-dinitrophenylhydrazine reacted to result in the corresponding 2,4- dinitrophenylhydrazones. These were extracted with $2 \mathrm{ml}$ of acetonitrile. The glass vials were shaken for approximately 30 minutes and the extract filtered through $0.45 \mu \mathrm{m}$ disc membrane filters and injected into the high-performance liquid chromatography (HPLC) system. The carbonyl concentrations were quantified with external calibrations curves constructed from standard solutions of TO11/IP6A carbonylDNPH Mix. The limit of detection (LOD) ranged from 1.29 to $2.09 \mu \mathrm{g} \mu \mathrm{l}^{-1}$.

The analyzed carbonyls studied here are alcohols (acetaldehyde - AM, methanol - AP, ethanol - AQ, isopropanol - AR) and cetones (acetone - AK).

\subsection{Statistical analysis}

Wilcoxon signed rank tests (Hollander \& Wolfe, 1973) were used to test differences between seasonal concentrations of the studied parameters. To investigate the association between independent variables (classroom characteristics) and dependent variables (measured parameters), for each dependent variable a linear model was first applied using all the ten independent variables characterizing the classrooms. The independent variables considered are: 1) level of classroom, 2) number of students per $\left.\mathrm{m}^{3}, 3\right)$ number of windows and doors opened, 4) type of board, 5) floor material, 6) ceiling material, 7) presence of heating device, 8) dusty surfaces, 9) number of cleanings per day, 10) view from classroom. The thirty-one dependent variables analysed are part of one of the following groups: 1) total particle mass, 2) chemical element mass, 3) mass of water soluble ions, 4) VOCs, 5) carbonyls.

Then, the independent variables were taken out from the model, one by one, in order to select the best model. The best model selected was the one that minimized the AIC (Akaike, 1974) and had all terms significant. This analysis was conducted in the statistics package R. All selected models have all terms significant at $5 \%$. The multiple R-squared refers to the fraction of variance explained by the model and was calculated for all selected models. 


\section{Results}

\subsection{Seasonal variability}

The seasonal variation of total particulate matter is resumed in Fig. 2. The results of the Wilcoxon signed rank tests indicated that the concentration of total particles in the air is lower in the spring than in the autumn $(p=0.001)$ and in the winter $(p<0.001)$. On the other hand, the tests showed no evidence to suggest a difference in the concentration of total particles in the air between the autumn and the winter $(p=0.76)$.

Fig. 3 shows the box plots of $\mathrm{Cr}, \mathrm{K}, \mathrm{Sb}, \mathrm{Sc}$ and $\mathrm{Zn}$ concentrations in autumn and winter in 28 classrooms of 14 schools. There is evidence to suggest that the air concentration is smaller in the winter than in the autumn for $\mathrm{Cr}(\mathrm{p}<0.001), \mathrm{K}(\mathrm{p}=0.03)$ and $\mathrm{Sb}(\mathrm{p}=0.016)$. On the contrary, there is no evidence supporting a difference between autumn and winter in the concentrations of $\mathrm{Sc}(\mathrm{p}=0.11)$ and $\mathrm{Zn}(\mathrm{p}=0.22)$.

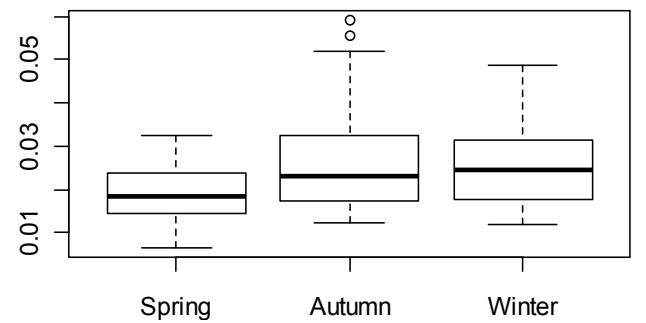

Fig. 2. Boxplot of TPM mass, in mg/day, in three seasons in 28 classrooms of 14 primary schools.

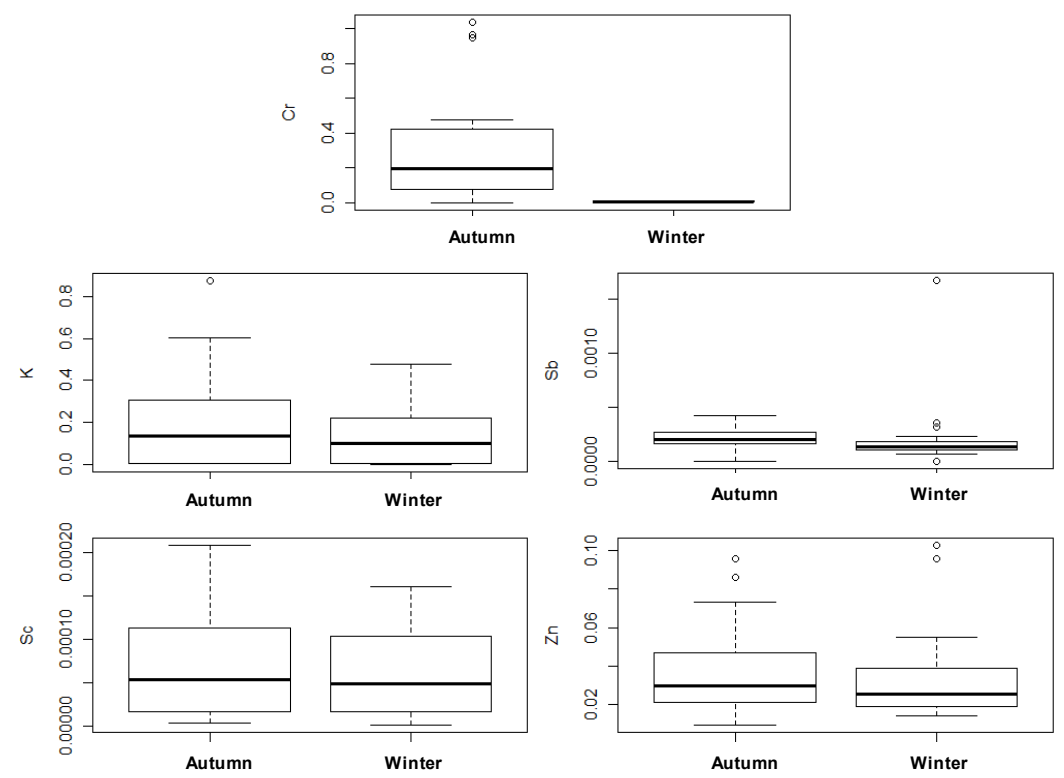

Fig. 3. Box plots of $\mathrm{Cr}, \mathrm{K}, \mathrm{Sb}, \mathrm{Sc}$ and $\mathrm{Zn}$ concentrations in autumn and winter in 28 classrooms of 14 primary schools. 
Figure 4 shows the seasonal variation of isooctane (AE) and acetone (AK). The statistical tests suggested that the air concentrations are larger in the winter than in the autumn for AA $(\mathrm{p}<0.001), \operatorname{AE}(\mathrm{p}<0.001)$ and AK $(\mathrm{p}<0.001)$.
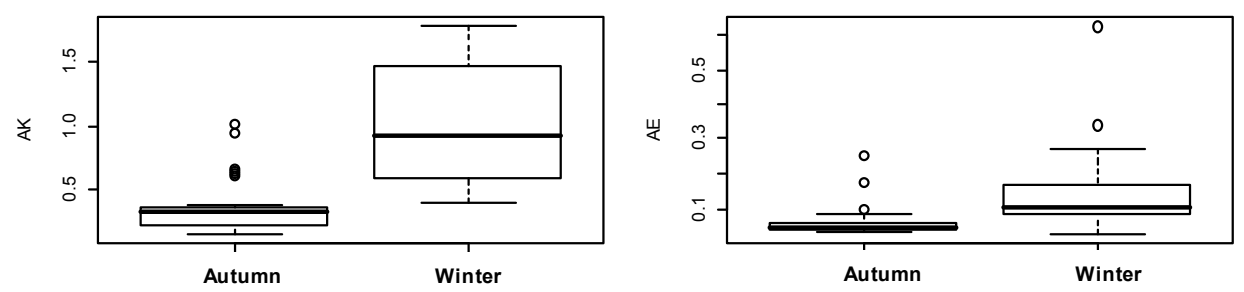

Fig. 4. Box plots of AE and AK concentrations in two seasons in 28 classrooms of 14 primary schools.

Seasonal variation of benzene (AW) and toluene (AY) are shown in Fig. 5. The test results supported that the concentration of AW in the air is lower in the spring than in the autumn $(p<0.001)$. There is also evidence that the concentration is smaller in the autumn than in the winter $(p<0.001)$. The results indicated no difference in the concentration of AY between the spring and the autumn $(p=0.20)$, but suggested that the concentration is smaller in the spring than in winter $(p<0.001)$ and also smaller in the autumn than in the winter $(p<0.001)$.

\subsection{Analysis of the association of the classroom characteristics and the particle} mass, water soluble ions, air concentration of certain elements VOCs and carbonyls

The results obtained are summarized in Tables 2-4. The effects (i.e. regression coefficients) are shown for variables with significant effects. Figure 6 illustrates the relation of some of these variables in boxplot charts.
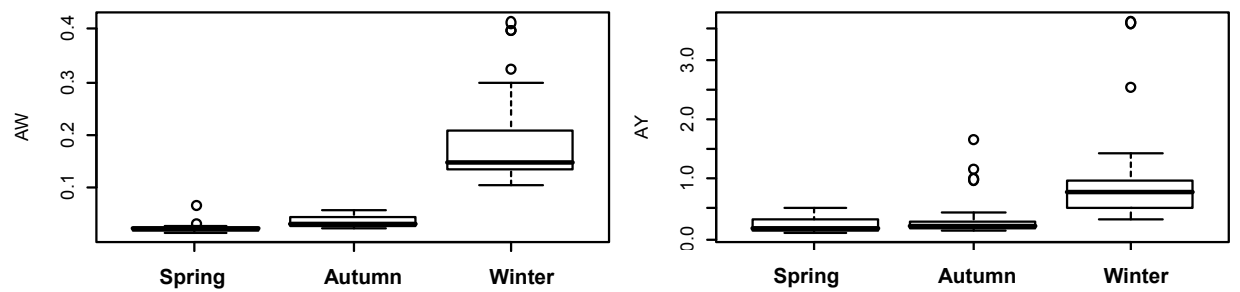

Fig. 5. Box plots of AW and AY concentrations in autumn and winter in 28 classrooms of 14 primary schools.

\subsubsection{Mass of total particulate matter}

In autumn and winter, $73 \%$ and $67 \%$ respectively of the variability across classrooms of the particle mass indoor is explained by the studied classroom characteristics. There are negative significant associations with the number of windows opened ( $p<0.01$ in autumn; $p<0.05$ in winter) and the existence of heating device $(p<0.001$ in autumn; and $p<0.05$ in winter). Classroom facing the street - as opposed to an inner patio - are associated with lower concentrations of particle mass indoor in both autumn and winter ( $p<0.001$ in autumn and $\mathrm{p}<0.01$ in winter). The ceiling material ( $\mathrm{p}<0.001$ in autumn and $\mathrm{p}<0.01$ in winter) has 
also a significant effect, with the results suggesting that wood may be associated with lower levels of particle mass indoor and false ceilings with higher levels of particle mass indoor. Regarding the particle mass in spring, none of the variables is significant at $5 \%$.

\subsubsection{Chemical elements in particulate mass}

Available measurements for the chemical elements refer all to the autumn season. The classroom characteristics considered in this study explained $57 \%$ of the variability of total chromium. Significant effects were found for: (i) the ceiling material $(p<0.05)$, with a positive association with wood ceilings, and (ii) the existence of a heating device $(p<0.05)$ with lower $\mathrm{Cr}$ when devices are present.

According to the value of the multiple $\mathrm{R}^{2}$, the floor and ceiling materials explain together $52 \%$ of the variation of the total antimony $(\mathrm{Sb})$ in particle mass indoor. The significant effects of floor material $(\mathrm{p}<0.05)$ and the ceiling material $(\mathrm{p}<0.01)$ suggest lower $\mathrm{Sb}$ amount in classrooms with vinyl floors and slab ceilings.

For total scandium (Sc) indoor in particle mass, $57 \%$ of its variation is explained by: (i) the number of windows/doors opened $(\mathrm{p}<0.05)$, which is negatively associated to Sc, (ii) the use of whiteboard with pen $(\mathrm{p}<0.01)$, which is associated to higher Sc amount, (iii) the ceiling material $(\mathrm{p}<0.05)$, with slab and wood associated to lower levels of Sc in the classroom, and (iv) the classroom facing the street as opposed to an inner patio, the former being negatively associated to the Sc amount in the classroom $(\mathrm{p}<0.05)$.

With $55 \%$ of the variability explained, the total zinc (Zn) indoor in particle mass displays significant effects for (i) the number of students per cubic meter (positive relation, $p<0.01$ ), (ii) the existence of a heating device in the classroom, with a negative relation $(p<0.05)$, (iii) the dust present in the classroom (negative relation, $\mathrm{p}<0.01$ ), and (iv) the number of cleanings per day (negative relation, $\mathrm{p}<0.001$ ).

For $\mathrm{Au}$ and $\mathrm{K}$, the variables studied only explain $16 \%$ and $35 \%$, respectively of their variation across classrooms. Higher concentrations of $\mathrm{Au}$ are associated with classrooms facing inner patios as opposed to a street $(p<0.05)$. Higher concentrations of $K$ are associated with fewer opened windows $(\mathrm{p}<0.05)$ and cork ceilings $(\mathrm{p}<0.05)$.

\subsubsection{Water-soluble ions in particulate mass}

All data on ions were collected in the winter season. The studied classroom characteristics appear to explain a large part of the variability across classrooms of chloride $(\mathrm{Cl})$, magnesium $\left(\mathrm{Mg}^{2+}\right)$ and sodium $\left(\mathrm{Na}^{+}\right)$ions (multiple $\mathrm{R}^{2}$ equals $0.81,0.77$ and 0.68 , respectively). On the contrary, few variation has been explained for the sulphate $\left(\mathrm{SO}_{4}{ }^{2-}\right)$ and calcium $\left(\mathrm{Ca}^{2+}\right)$ ions, as the multiple $\mathrm{R}^{2}$ are relatively low ( 0.18 and 0.25 , respectively). This suggests that other factors, not included in this study may be responsible for the variability of these ions.

The sodium and chloride ions present significant associations with almost the same group of variables. Namely, both ions present significant associations with the floor level of the classroom $(p<0.05)$ suggesting lower concentrations in the ground and 1st floors. The floor and the ceiling materials also have significant effects on these two ions with wooden floors and ceilings presenting the lowest coefficient and thus associated with lower concentrations. False ceilings are, on the contrary, associated with higher concentrations. In addition, the number of cleanings per day also has a significant negative effect $\left(\mathrm{Na}^{+}: \mathrm{p}<0.05 ; \mathrm{Cl}: \mathrm{p}<0.001\right)$, with higher numbers being associated with lower concentrations of the water soluble $\mathrm{Na}^{+}$and $\mathrm{Cl}$ - indoor. The results indicate that the use of whiteboard with pen - as opposed to blackboard with chalk 
- is associated with higher levels of the soluble ion $\mathrm{Cl}^{-}$indoor $(\mathrm{p}<0.01)$ and a larger number of windows/doors opened is associated with lower levels of $\mathrm{Na}^{+}$indoors.

Significant effects on water soluble $\mathrm{Mg}^{2+}$ and $\mathrm{K}^{+}$were found for exactly the same classroom characteristics. The results show significant effects with floor material $\left(\mathrm{Mg}^{2+}: \mathrm{p}<0.001 ; \mathrm{K}+\right.$ : $\mathrm{p}<0.01)$, ceiling material $\left(\mathrm{Mg}^{2+}: \mathrm{p}<0.001 ; \mathrm{K}+: \mathrm{p}<0.05\right)$ and number of cleanings per day $\left(\mathrm{Mg}^{2+}: \mathrm{p}<0.01 ; \mathrm{K}+\mathrm{p}<0.05\right)$. Higher number of cleanings as well as wood in floors and ceilings are associated with lower concentrations of $\mathrm{Mg}^{2+}$ and $\mathrm{K}^{+}$. False ceilings as well as plastic and vinyl floors are associated with higher concentrations.

\begin{tabular}{|c|c|c|c|c|c|c|c|c|}
\hline \multirow[b]{2}{*}{$\begin{array}{l}\text { Independent } \\
\text { variables }\end{array}$} & \multicolumn{8}{|c|}{ Dependent variable } \\
\hline & $\begin{array}{c}\text { Particle } \\
\text { mass } \\
\text { autumn }\end{array}$ & \begin{tabular}{|c|} 
Particle \\
mass \\
winter
\end{tabular} & $\begin{array}{c}\mathrm{Au} \\
\text { autumn }\end{array}$ & $\begin{array}{c}\mathrm{Cr} \\
\text { autumn }\end{array}$ & \begin{tabular}{|c|}
$\mathbf{K}$ \\
autum \\
$\mathbf{n}$
\end{tabular} & $\begin{array}{c}\mathrm{Sb} \\
\text { autumn }\end{array}$ & Sc autumn & $\begin{array}{c}\mathrm{Zn} \\
\text { autumn }\end{array}$ \\
\hline Floor level & & $p<0.05$ & & & & & & \\
\hline - basement & & 0 & & & & & & \\
\hline - ground floor & & -0.0342 & & & & & & \\
\hline -1st floor & & -0.0312 & & & & & & \\
\hline Students $/ \mathbf{m}^{3}$ & & & & & & & & $0.2310^{* *}$ \\
\hline $\begin{array}{l}\text { Nr windows \& } \\
\text { doors opened }\end{array}$ & $-0.0063^{* *}$ & $-0.0050^{*}$ & & & \begin{tabular}{c|}
- \\
$0.1124^{*}$ \\
\end{tabular} & & $-0.0000331^{*}$ & \\
\hline $\begin{array}{c}\text { Whiteboard with } \\
\text { pen } \\
\text { (vs blackboard with } \\
\text { chalk) }\end{array}$ & & & & & & & $\begin{array}{c}0.0001064^{*} \\
*\end{array}$ & \\
\hline Floor material & & & & & & $\mathrm{p}<0.05$ & & \\
\hline - brick floor & & & & & & 0 & & \\
\hline - plastic floor & & & & & & 0.000134 & & \\
\hline - vinyl floor & & & & & & $\begin{array}{c}- \\
0.000122 \\
\end{array}$ & & \\
\hline - wooden floor & & & & & & $\begin{array}{c}- \\
0.000063 \\
\end{array}$ & & \\
\hline Ceiling material & $\mathrm{p}<0.001$ & $\mathrm{p}<0.01$ & & $\mathrm{p}<0.05$ & $p<0.05$ & $\mathrm{p}<0.01$ & $p<0.05$ & \\
\hline - cork & 0 & 0 & & 0 & 0 & 0 & 0 & \\
\hline - slab & -0.0133 & -0.0091 & & -0.0193 & -0.2842 & $\begin{array}{c}- \\
0.000130 \\
2\end{array}$ & -0.0000769 & \\
\hline - false & 0.0088 & 0.0042 & & -0.1652 & -0.3538 & $\begin{array}{c}- \\
0.000001 \\
6 \\
\end{array}$ & -0.0000093 & \\
\hline - wood & -0.0353 & -0.0363 & & 0.5571 & -0.5319 & $\begin{array}{c}0.000075 \\
0\end{array}$ & -0.0001651 & \\
\hline Heating device & $-0.0153^{* * *}$ & $-0.0089^{*}$ & & $-0.2163^{*}$ & & & & $-0.0175^{*}$ \\
\hline Dust & & & & & & & & $-0.0281^{* *}$ \\
\hline $\begin{array}{c}\text { Nr cleanings per } \\
\text { day }\end{array}$ & & & & & & & & $\begin{array}{c}- \\
0.0265^{* * *}\end{array}$ \\
\hline $\begin{array}{c}\text { Classroom faces } \\
\text { street }\end{array}$ & $-0.0159^{* * *}$ & $-0.0115^{* *}$ & $-0.00056^{*}$ & & & & \begin{tabular}{|c|}
- \\
$0.0000460^{*}$
\end{tabular} & \\
\hline Multiple $\mathbf{R}^{2}$ & 0.73 & 0.67 & 0.16 & 0.57 & 0.35 & 0.52 & 0.57 & 0.55 \\
\hline
\end{tabular}

Table 2. Regression coefficients and their significance for particle mass and elements (significant codes: ${ }^{* * *}<0.001 ;{ }^{* *}<0.01 ;{ }^{*}<0.05$ ). 


\begin{tabular}{|c|c|c|c|c|c|c|c|c|c|}
\hline \multirow[b]{2}{*}{ Independent variables } & \multicolumn{9}{|c|}{ Dependent variable } \\
\hline & $\mid \begin{array}{c}\mathrm{Ca}^{2+} \\
\text { winter }\end{array}$ & $\underset{\text { winter }}{\mathrm{Cl}^{-}}$ & $\mid \begin{array}{c}\mathrm{F}^{-} \\
\text {winter }\end{array}$ & $\begin{array}{c}\mathbf{K}^{+} \\
\text {winter }\end{array}$ & $\underset{\text { winter }}{\mathrm{Mg}^{2+}}$ & $\begin{array}{c}\mathrm{NO}_{3}^{-} \\
\text {winter }\end{array}$ & $\begin{array}{c}\mathrm{Na}^{+} \\
\text {winter }\end{array}$ & $\begin{array}{c}\mathrm{PO}_{4}^{3-} \\
\text { winter }\end{array}$ & $\mid \begin{array}{c}\mathrm{SO}_{4}^{2-} \\
\text { winter }\end{array}$ \\
\hline Floor level & & $\mathrm{p}<0.05$ & & & & & $\mathrm{p}<0.05$ & & \\
\hline - basement & & 0 & & & & & 0 & & \\
\hline - ground floor & & -0.6596 & & & & & -0.7448 & & \\
\hline - 1st floor & & -0.5600 & & & & & -0.3035 & & \\
\hline \multicolumn{10}{|l|}{ Students $/ \mathrm{m}^{3}$} \\
\hline $\begin{array}{c}\text { Nr windows \& doors } \\
\text { opened }\end{array}$ & & & & & & & $-0.1666^{*}$ & & \\
\hline $\begin{array}{l}\text { Whiteboard with pen } \\
\text { (vs blackboard with } \\
\text { chalk) }\end{array}$ & & $0.4396^{* *}$ & $0.1064^{* *}$ & & & $0.1828^{*}$ & & $0.2052^{* * *}$ & \\
\hline Floor material & & $\mathrm{p}<0.001$ & & $\mathrm{p}<0.01$ & $p<0.001$ & $p<0.05$ & $\mathrm{p}<0.05$ & & \\
\hline - brick floor & & 0 & & 0 & 0 & 0 & 0 & & \\
\hline - plastic floor & & 0.3109 & & 0.0056 & 0.0459 & 0.0257 & -0.2721 & & \\
\hline - vinyl floor & & 0.1965 & & 0.1705 & 0.0431 & -0.1613 & -0.1189 & & \\
\hline - wooden floor & & -0.3508 & & -0.1227 & -0.0358 & -0.1443 & -0.5700 & & \\
\hline Ceiling material & & $\mathrm{p}<0.01$ & $\mathrm{p}<0.05$ & $\mathrm{p}<0.05$ & $p<0.001$ & & $\mathrm{p}<0.05$ & & \\
\hline - cork & & 0 & 0 & 0 & 0 & & 0 & & \\
\hline - slab & & -0.2038 & -0.0757 & -0.0530 & 0.0183 & & -0.2732 & & \\
\hline - false & & 0.2279 & -0.0265 & 0.1054 & 0.0600 & & 0.3312 & & \\
\hline - wood & & -0.7294 & -0.0461 & -0.2578 & -0.0439 & & -1.0030 & & \\
\hline Heating device & $\begin{array}{c}- \\
0.7883^{*} \\
*\end{array}$ & & & & & $\begin{array}{c}- \\
0.1740^{* *}\end{array} \mid$ & & & $-1.3769^{*}$ \\
\hline \multicolumn{10}{|l|}{ Dust } \\
\hline Nr cleanings per day & & $-0.4039^{* * *}$ & $-0.0536^{*}$ & $-0.1226^{*}$ & $\mid \begin{array}{c}- \\
0.0273 * *\end{array}$ & $\begin{array}{c}- \\
0.1469^{* *}\end{array}$ & $-0.3245^{*}$ & & \\
\hline $\begin{array}{l}\text { Classroom faces street } \\
\text { (vs inner patio) }\end{array}$ & & & $\begin{array}{c}- \\
0.0493^{* *}\end{array}$ & & & & & $-0.0587^{*}$ & \\
\hline Multiple $\mathbf{R}^{2}$ & 0.25 & 0.81 & 0.54 & 0.56 & 0.77 & 0.64 & 0.68 & 0.43 & 0.18 \\
\hline
\end{tabular}

Table 3. Regression coefficients and their significance for water soluble ions (significant codes: $\left.{ }^{* *}<0.001 ;{ }^{* *}<0.01 ;{ }^{*}<0.05\right)$. 


\begin{tabular}{|c|c|c|c|c|c|c|c|c|c|}
\hline \multirow[b]{2}{*}{$\begin{array}{l}\text { Independent } \\
\text { variables }\end{array}$} & \multicolumn{9}{|c|}{ Dependent variable } \\
\hline & $\begin{array}{c}\mathrm{AC} \\
\text { winter }\end{array}$ & \begin{tabular}{|}
$\mathrm{AD}$ \\
spring
\end{tabular} & $\begin{array}{c}\mathrm{AE} \\
\text { autumn }\end{array}$ & $\underset{\text { winter }}{\mathrm{AE}}$ & $\begin{array}{c}\text { AF } \\
\text { spring }\end{array}$ & $\begin{array}{c}\mathrm{AK} \\
\text { autumn }\end{array}$ & $\mid \begin{array}{c}\text { AM } \\
\text { spring }\end{array}$ & $\begin{array}{c}\mathrm{AP} \\
\text { winter }\end{array}$ & $\begin{array}{c}\mathrm{AQ} \\
\text { winter }\end{array}$ \\
\hline Floor level & & & $\mathrm{p}<0.01$ & & & $\mathrm{p}<0.01$ & & & $\mathrm{p}<0.001$ \\
\hline - basement & & & 0 & & & 0 & & & 0 \\
\hline - ground floor & & & -0.1111 & & & -0.0400 & & & -4.3574 \\
\hline - 1st floor & & & -0.0766 & & & -0.2712 & & & -4.1025 \\
\hline Students/m $\mathbf{m}^{3}$ & $7.2989 * * *$ & & & $1.4412^{* *}$ & & & & $6.7938 * * *$ & \\
\hline $\begin{array}{c}\text { Nr windows \& doors } \\
\text { opened }\end{array}$ & & & & & & $-0.1083^{* *}$ & & & $0.3988^{* *}$ \\
\hline $\begin{array}{c}\text { Whiteboard with pen } \\
\text { (vs blackboard with } \\
\text { chalk) }\end{array}$ & & & & & & & & & \\
\hline Floor material & & $p<0.001$ & & & $p<0.01$ & & & & \\
\hline - brick floor & & 0 & & & 0 & & & & \\
\hline - plastic floor & & 0.2467 & & & 0.5396 & & & & \\
\hline - vinyl floor & & -0.0455 & & & -0.0671 & & & & \\
\hline - wooden floor & & 0.0047 & & & -0.0624 & & & & \\
\hline Ceiling material & & & $\mathrm{p}<0.001$ & & & $\mathrm{p}<0.01$ & & & \\
\hline - cork & & & 0 & & & 0 & & & \\
\hline - slab & & & -0.0829 & & & -0.3390 & & & \\
\hline - false & & & -0.0624 & & & -0.0431 & & & \\
\hline - wood & & & -0.1451 & & & -0.4950 & & & \\
\hline Heating device & & $-0.0427^{*}$ & $-0.0561^{* * *}$ & & & & & & \\
\hline Dust & $-0.3884^{* *}$ & & & & & & & & \\
\hline $\mathrm{Nr}$ cleanings per day & $-0.2329^{*}$ & & & & & & $0.0919^{*}$ & $-0.2940^{*}$ & \\
\hline $\begin{array}{l}\text { Classroom faces } \\
\text { street (vs inner } \\
\text { patio) }\end{array}$ & & & $-0.0446^{* *}$ & & & $-0.3724^{* * *}$ & & & \\
\hline Multiple $\mathbf{R}^{2}$ & 0.69 & 0.71 & 0.80 & 0.25 & 0.43 & 0.70 & 0.21 & 0.52 & 0.66 \\
\hline
\end{tabular}

Table 4. Regression coefficients and their significance for VOCs and carbonyls (significant codes: $\left.{ }^{* * *}<0.001 ;{ }^{* *}<0.01 ;{ }^{*}<0.05\right)$. 


\begin{tabular}{|c|c|c|c|c|c|c|c|c|}
\hline \multirow[b]{2}{*}{$\begin{array}{l}\text { Independent } \\
\text { variables }\end{array}$} & \multicolumn{8}{|c|}{ Dependent variable } \\
\hline & $\begin{array}{c}\mathrm{AR} \\
\text { winter }\end{array}$ & $\begin{array}{c}\mathrm{AW} \\
\text { autumn }\end{array}$ & $\begin{array}{c}\mathrm{AW} \\
\text { winter }\end{array}$ & $\begin{array}{c}\mathrm{AY} \\
\text { autumn }\end{array}$ & $\begin{array}{c}\mathrm{AZ} \\
\text { spring }\end{array}$ & $\begin{array}{c}\text { BA } \\
\text { spring }\end{array}$ & $\begin{array}{c}\text { BC } \\
\text { spring }\end{array}$ & $\begin{array}{c}\text { BT } \\
\text { autumn }\end{array}$ \\
\hline Floor level & & $\mathrm{p}<0.01$ & & $\mathrm{p}<0.001$ & & & & $\mathrm{p}<0.01$ \\
\hline - basement & & 0 & & 0 & & & & 0 \\
\hline - ground floor & & -0.0209 & & -1.0466 & & & & -1.3435 \\
\hline - 1st floor & & -0.0213 & & -0.8763 & & & & -0.0700 \\
\hline Students $/ \mathrm{m}^{3}$ & & $0.0953^{* *}$ & & & & & & \\
\hline $\begin{array}{c}\text { Nr windows \& doors } \\
\text { opened }\end{array}$ & & & & & & & $0.0765^{*}$ & \\
\hline \begin{tabular}{|c|} 
Whiteboard with \\
pen \\
(vs blackboard with \\
chalk)
\end{tabular} & & & $0.1659^{* *}$ & & & & & \\
\hline Floor material & $\mathrm{p}<0.05$ & $\mathrm{p}<0.05$ & & & $\mathrm{p}<0.01$ & $\mathrm{p}<0.001$ & $\mathrm{p}<0.05$ & \\
\hline - brick floor & 0 & 0 & & & 0 & 0 & 0 & \\
\hline - plastic floor & -10.600 & -0.0133 & & & 0.8501 & 2.6104 & 0.5389 & \\
\hline - vinyl floor & -32.898 & -0.0124 & & & -0.0658 & -0.0758 & 0.0505 & \\
\hline - wooden floor & -7.592 & -0.0052 & & & -0.0621 & -0.0730 & 0.0299 & \\
\hline Ceiling material & & & $\mathrm{p}<0.05$ & $\mathrm{p}<0.001$ & & & & $\mathrm{p}<0.001$ \\
\hline - cork & & & 0 & 0 & & & & 0 \\
\hline$-s l a b$ & & & -0.0991 & -0.4104 & & & & -2.2013 \\
\hline - false & & & -0.1306 & -0.0273 & & & & -2.3441 \\
\hline - wood & & & 0.0764 & 0.0460 & & & & -3.6549 \\
\hline Heating device & $-35.232^{* * *}$ & $-0.0126^{* * *}$ & & $-0.2995^{* * *}$ & & & & $-1.3108^{* *}$ \\
\hline Dust & $27.212^{* *}$ & $0.0094^{* *}$ & $-0.1069^{*}$ & & & & & \\
\hline Nr cleanings per day & & & $-0.0889^{*}$ & & & & & \\
\hline $\begin{array}{l}\text { Classroom faces } \\
\text { street (vs inner } \\
\text { patio) }\end{array}$ & & $-0.0116^{* * *}$ & & $-0.2173^{* *}$ & & & & \\
\hline Multiple $\mathbf{R}^{2}$ & 0.53 & 0.82 & 0.53 & 0.92 & 0.46 & 0.78 & 0.40 & 0.69 \\
\hline
\end{tabular}

Table 4. (cont.). Regression coefficients and their significance for VOCs and carbonyls (significant codes: ${ }^{* * *}<0.001 ;{ }^{* *}<0.01 ;{ }^{*}<0.05$ ). 

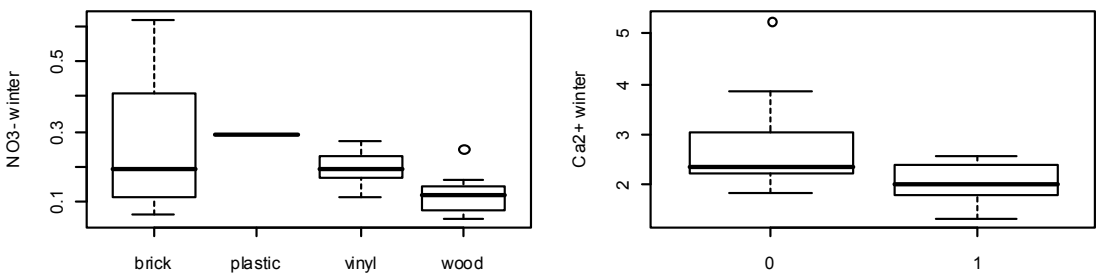

Floor material
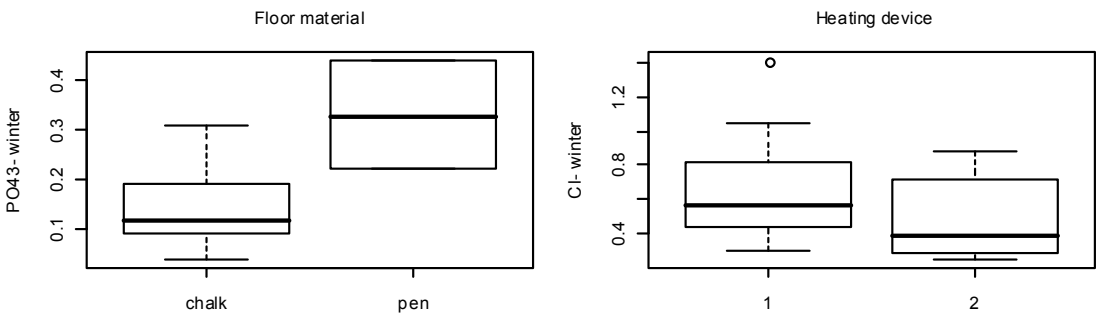

Board type
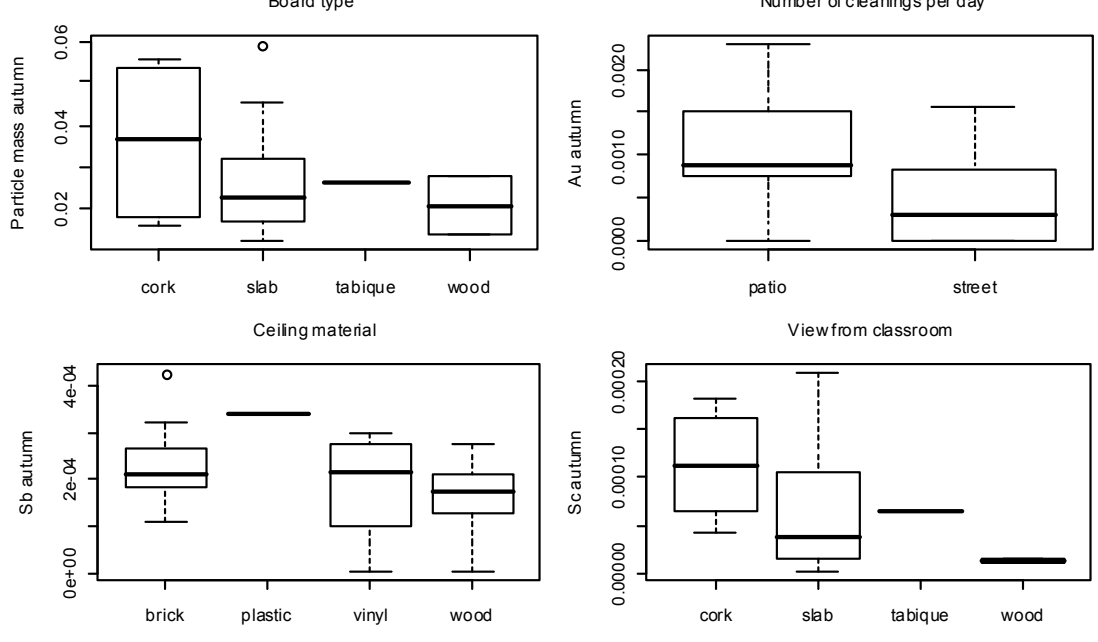

Floor material
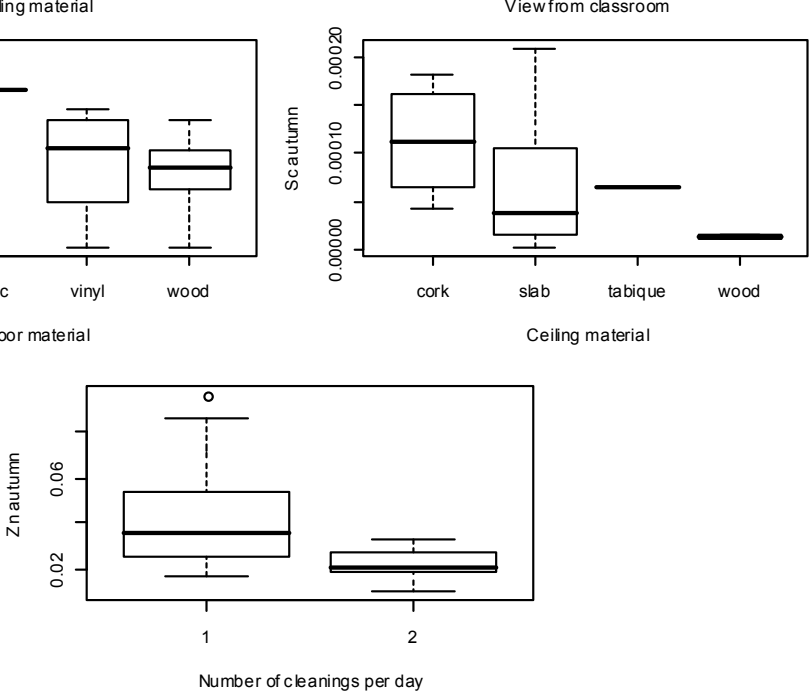

Fig. 6. Boxplot for significant parameters (selected examples).

The results for the water soluble $\mathrm{F}^{-}$indoor indicate significant effects for the use of whiteboard with pen $(p<0.01)$, the ceiling material $(p<0.05)$, the number of cleanings per day 
$(\mathrm{p}<0.05)$, and classroom facing street/inner patio $(\mathrm{p}<0.01)$. The amount of $\mathrm{F}^{-}$seems to be lowest in classrooms with slab ceilings, facing the street, using blackboard with chalk and having more cleanings per day.

For the water soluble $\mathrm{NO}_{3}$ - indoor, significant effects were found for the use of whiteboard with pen versus backboard with chalk $(p<0.05)$, the floor material $(p<0.05)$, the number of cleaning per day $(p<0.01)$ and the presence of a heating device $(p<0.01)$. Higher levels of this ion are associated with plastic floors, whereas vinyl and wooden floors, presence of heating device and higher number of cleanings are associated with lower concentrations.

The ion $\mathrm{PO}_{4}^{3-}$ shows significant effects for use of whiteboard with pen $(\mathrm{p}<0.001)$ and classroom facing street/inner patio $(\mathrm{p}<0.05)$. Classrooms using whiteboard with pen and facing inner patios are associated with higher concentrations of this ion.

\subsubsection{VOCs and carbonyls}

Toluene (AY) and isooctane (AE), both collected in autumn, present significant effects for the same variables: floor level ( $p<0.001$ for AY; $p<0.01$ for $A E)$, ceiling material $(p<0.001)$, heating device $(p<0.001)$ and classroom facing street/inner patio $(p<0.01)$. These variables explain $92 \%$ and $80 \%$ of variability of $\mathrm{AY}$ and AE, respectively. For both VOCs, higher concentrations are associated with classrooms in the basement, facing inner patios or without heating devices. Classrooms with wooden ceilings are associated with higher levels of AY while classrooms with cork ceilings are associated with higher levels of AE. Lower concentrations of AY and AE are associated with classrooms on the ground floor, with heating devices, facing the street. Classrooms with slab ceilings are associated with lower levels of AY and those with wooden ceilings are associated with lower levels of AE.

No significant effects were found for the spring and winter measurements of AY and the autumn measurement of AE.

Benzene (AW) was measured in spring, autumn and winter, but only the autumn and winter measurements show significant effects with variables considered in this study, which explained $82 \%$ and $53 \%$, respectively, of the variation of those measurements. For the autumn measurement, significant effects were found for floor level $(p<0.01)$, floor material $(p<0.05)$, presence of heating device $(p<0.001)$, dust in surfaces $(p<0.01)$ and classroom facing the street/inner patio $(p<0.001)$. In particular, the effects are positive for dust in surfaces and negative for presence of heating device and classroom facing the street. Classrooms in the basement and with brick floors are associated with higher concentration of AW in autumn.

The concentration of $\mathrm{AW}$ in winter was shown to be significantly larger from that in the autumn (see section 3.1) and the set of variables with significant effects is also different. In winter, the floor level, the floor material, the heating device and the classroom facing the street/inner patio are no longer significant. Instead, significant effects were found with the type of board $(p<0.01)$, the ceiling material $(p<0.05)$, dust $(p<0.05)$ and the number of cleanings per day $(p<0.05)$. Wooden ceilings, the use of whiteboard with pen, and lower number of cleanings were associated with higher concentration of $\mathrm{AW}$, whereas slab and false ceilings, the use of blackboard with chalk, and higher number of cleanings were associated with lower concentrations of AW. The variable dust, which showed a positive significant effect in autumn, has on the contrary a negative significant effect in the winter. The $\mathrm{m}+\mathrm{p}$ xylene (BA) indoor was collected in spring and $78 \%$ of its variation is explained by one variable alone, the floor material $(\mathrm{p}<0.001)$. Classrooms with plastic floors are associated 
with higher concentrations of this VOC. The n-hexane (AD) indoor, also collected in spring, shows as well a significant effect with floor material $(\mathrm{p}<0.001)$ and classrooms with plastic floors are again associated with higher concentrations. The presence of a heating device shows too a significant effect $(\mathrm{p}<0.05)$, with classroom with heating devices associated with lower concentrations. Floor material and heating device explained $71 \%$ of the variation of this VOC.

Acetone (AK) was measured in autumn and winter but only the autumn measurements displayed significant effects with the variables studied here, namely floor level $(p<0.01)$, number of windows and doors opened $(p<0.01)$, ceiling material $(p<0.01)$ and classroom facing the street/inner patio $(\mathrm{p}<0.001)$. Altogether, these four variables explain $70 \%$ of the variation of $\mathrm{AK}$ in autumn. Higher floors and larger number of windows/doors opened are associated with lower concentrations. The ceiling materials associated with lower concentrations are slab and wood, and those with higher are false ceilings and cork ceilings. Classrooms facing the street are associated with lower concentrations of AK.

Indoor 2-methylpentane $(\mathrm{AC})$ in winter displayed a positive significant effect for the number of students per $\mathrm{m}^{3}(\mathrm{p}<0.001)$ and negative significant effects for the number of cleanings per day $(p<0.05)$ and for dust $(p<0.01)$. These three variables explained $69 \%$ of variation of AC.

Cychlohexane (BT), collected in autumn, is significantly associated to floor level $(\mathrm{p}<0.01)$, ceiling material $(p<0.001)$ and existence of heating device $(p<0.01)$, which explain $69 \%$ of variation of BT. The ground floor is associated with lower concentrations and the basement with higher concentrations; cork ceilings and classrooms without heating devices are associated with higher concentrations.

The model selected for ethanol (AQ) indoor presents two variables with significant effects explaining $66 \%$ of the variation of this carbonyl: the floor level $(p<0.001)$ - the basement is associated with higher concentrations - and the number of windows opened $(p<0.01)$ with higher ethanol indoor associated with larger numbers of opened windows/doors.

The model selected for isopropanol (AR) indoor explains $53 \%$ of its variation and contains three variables with significant effects: floor material $(\mathrm{p}<0.05)$ - vinyl associated to lower concentrations and brick with higher concentrations -, heating device $(p<0.001)$ - presence of device associated with lower concentrations - and the existence of dust overall $(p<0.01)$ associated with higher concentrations.

The methanol (AP) indoor displays a positive significant effect for the number of students per cubic meter $(p<0.001)$ and a negative significant effect for the number of cleanings per day $(\mathrm{p}<0.05)$. The two variables explain $52 \%$ of the variation of AP.

For all other VOCs and carbonyls, the multiple $\mathrm{R}^{2}$ is less than $50 \%$ and the selected models contain at most two variables with significant effects. It may be worth noting the positive significant effect for students per cubic meter for $\mathrm{AE}$ in winter. The floor material shows significant effects in the models for $\mathrm{AZ}, \mathrm{AF}$ and $\mathrm{BC}$ (all collected in spring).

\section{Discussion and conclusions}

In this study, models were applied to several components of the air to investigate associations with classrooms characteristics. Some patterns emerged across these analyses:

- Classrooms facing a street seem to have lower air concentrations of several components than those facing an inner patio. This could be linked to ventilation issues as inner 
patios may generate less air movement and consequent accumulation of some components. Classrooms facing the inner patios are associated with higher concentration of $\mathrm{Au}, \mathrm{Sc}, \mathrm{PO}_{4}{ }^{3-}, \mathrm{F}-$, isooctane - $\mathrm{AE}$ (autumn), acetone - $\mathrm{AK}$, benzene - $\mathrm{AW}$ (autumn) and toluene - AY, as well as TPM mass with less particle mass in the autumn and winter.

- Classrooms with higher number of windows/doors opened were associated with less particle mass, $\mathrm{K}, \mathrm{Sc}$, acetone - $\mathrm{AK}$ and $\mathrm{Na}^{+}$in the air, possibly due to increased ventilation. However, a larger number of opened windows/doors was also associated with more o-xylene - BC and ethanol - AQ, which suggests outdoor sources for these two components.

- Crowded classrooms seem to lead to increased concentrations of several components. The density of students per $\mathrm{m}^{3}$ was found to be positively associated with the concentrations of Zn, 2-methylpentane - AC, methanol - AP, isooctane - AE (winter) and benzene - AW (autumn).

- Classrooms located in basements seem to suffer from accumulation of several components, perhaps due to lack of ventilation. The results indicated that the air of the classrooms in the basement tended to have more particle mass, cyclohexane - BT, ethanol $\mathrm{AQ}$, isooctane - AE, acetone - AK, benzene - AW (autumn), toluene - $\mathrm{AY}, \mathrm{Na}^{+}$and $\mathrm{Cl}^{-}$.

- Cleanings appear to contribute to a decrease in several air components, but to an increase of others. It is possible that some components of the cleaning products pass into the air. Classrooms with higher number of cleanings a day were associated with higher concentrations of acetaldehyde - $\mathrm{AM}$ but reduced concentrations of $\mathrm{Zn}$, several ions $\left(\mathrm{Na}^{+}, \mathrm{Cl}^{-}, \mathrm{K}^{+}, \mathrm{NO}_{3}{ }^{-}, \mathrm{F}^{-}, \mathrm{Mg}^{2+}\right)$, 2-methylpentane - $\mathrm{AC}$, methanol - $\mathrm{AP}$ and benzene AW (winter).

- The results suggest that the air of dusty classrooms also favours increased concentrations of some elements, VOCs and carbonyls but is associated with lower concentrations of others; no association was found with ions. Namely, dusty classrooms were associated with lower levels of Zn, 2-methylpentane - AC, benzene - AW in winter, but higher levels of isopropanol - AR and benzene - AW in autumn. Although the presence of dust is likely to be due to less thorough cleanings, there may also be accumulation of components in the dust which would be thrown to the air by cleaning tasks.

- The presence of a heating device seems to be related to lower concentrations of a number of components, such as particle mass, $\mathrm{Cr}, \mathrm{Zn}, \mathrm{Ca}^{2+}, \mathrm{SO}_{4}{ }^{2-}$ and $\mathrm{NO}_{3} ;$; n-hexane $\mathrm{AD}$, isooctane - AE (autumn), isopropanol - AR, benzene - AW (autumn), toluene - AY (autumn) and cyclohexane - BT. Future analyses on the type and frequency of heating devices used will be needed to reveal the mechanism underlying these associations.

- Chalk and whiteboard pens are expected to liberate distinct substances. The use of whiteboard pens was associated with higher concentrations of Sc, benzene - AW (winter), $\mathrm{Cl}^{-}, \mathrm{PO}_{4}^{3-}, \mathrm{NO}_{3}^{-}$and $\mathrm{F}^{-}$.

- Different construction materials appear to impact on specific elements. Overall, wood seems to lead to a reduced concentration of several elements. Wooden ceilings in particular were associated with lower concentrations of particle mass, K, Sc, cyclohexane - BT, isooctane - AE (autumn) and acetone - AK; wooden ceilings and floors were associated with lower concentrations of $\mathrm{Na}^{+}, \mathrm{Cl}^{-}, \mathrm{Mg}^{2+}$ and $\mathrm{K}^{+}$. Plastic floors on the contrary were associated with higher concentrations of several components, 
including $\mathrm{Sb}$; VOCs such as n-hexane - $\mathrm{AD}$, n-heptane - $\mathrm{AF}$, ethylbenzene - $\mathrm{AZ}, \mathrm{m}+\mathrm{p}$ xylene - BA and o-xylene - BC; several ions, like $\mathrm{Cl}-, \mathrm{Mg}^{2+}$ and $\mathrm{NO}_{3}$. These results support evidence on the emissions of hazardous substances from buildings and construction materials (WHO, 2010; Carrer et al., 2002), but must be interpreted with caution as there is only one classroom with plastic floor and one school (two classrooms) with wooden ceilings. The significant effects observed could be associated with other factors present in that particular classroom/school.

Few components in this study were measured for more than one season. The seasonal analysis, albeit limited, suggested higher concentrations in winter as compared to spring of particle mass and of two VOCs, benzene - AW and toluene - AY. Spring being the season when windows tend to be open due to higher temperatures, these results suggest that these components get trapped in classrooms for lack of ventilation.

The concentrations of isooctane - $\mathrm{AE}$ and acetone - $\mathrm{AK}$ as well as benzene - $\mathrm{AW}$ and toluene - AY seem to be higher in winter than in autumn. For some elements, namely $\mathrm{Cr}, \mathrm{K}$ and $\mathrm{Sb}$, the concentrations seem, on the contrary, to be higher in autumn than in winter.

This study suggests the importance of cleaning and ventilation practices as well as construction materials on the indoor air quality in schools. It is known for example that benzene - AW has adverse health effects. The results obtained here suggest that lower concentrations of benzene - AW may be obtained with less crowded and better ventilated classrooms, frequent cleanings and by avoiding the use of whiteboard pens.

Overall, the conclusions of this study point to the following recommendations: 1) classrooms should face streets rather than patios and should not be located in basements, 2) the density of students can affect the indoor environment and should be limited, 3) wooden materials appear to have advantages as building materials due to a lower input of contaminants. In this work, wood did not contribute to an increase of the VOCs, as reported in previous research (Norback et al., 1995). Other factors, like ventilation, cleanings and use of chalk versus whiteboard pens, can reduce or increase specific contaminants inside the classrooms.

Therefore, caution is suggested when deciding on building materials for schools and on school practices, such as cleaning and boards, as these may affect the indoor air which children will breathe for long periods of the day.

\section{Acknowledgment}

Financial support by Fundação para a Ciência e a Tecnologia (FCT; Portugal) through research contract PTDC/SAU-ESA/65597/2006 is gratefully acknowledged. Dr. Susana Marta Almeida thanks FCT for Ciência 2007 support. The views expressed herein are those of the author(s) and do not necessarily reflect the views of the United Nations.

\section{References}

Akaike, H. (1974). A new look at statistical model idemtification. IEEE Transactions on Automatic Control, AU-19, 716-722. 
Allen, A.G. \& Miguel, A.H. (1995). Indoor organic and inorganic pollutants: in-situ formation and dry deposition in southeastern Brazil. Atmospheric Environment, Vol.29, No.23, pp. 3519-3526, ISSN 1352-2310

Almeida, S.M.; Canha, N.; Silva, A.; Freitas, M.C.; Pegas, P.; Alves, C.; Evtyugina, M. \& Pio, C.A. (2010) Children exposure to air particulate matter in indoor of Lisbon primary schools. Atmospheric Environment, ISSN 1352-2310 (in press; doi:10.1016/j.atmosenv.2010.11.052).

Bayer, C. W., Crow, S. \& Fischer, J. (2000). Causes of indoor air quality problems in schools. Summary of Scientific Research, USA: Energy Division Oak Ridge National Laboratory for the U.S. Department of Energy.

Canha, N.; Freitas, M.C.; Almeida, S.M.; Almeida, M.; Ribeiro, M.; Galinha, C. \& Wolterbeek, Hh.T. (2010). Indoor school environment: easy and low cost to assess inorganic pollutants. Journal of Radioanalytical and Nuclear Chemistry, Vol.286, No.2, pp. 495-500, ISSN 1588-2780

Canha, N.; Almeida, M.; Freitas, M.C.; Almeida, S.M. \& Wolterbeek, Hh.T. (2011). Seasonal variation of total particulate matter and children respiratory diseases at Lisbon primary schools using passive methods. Procedia Environmental Sciences, Vol.4, pp. 170-183, ISSN 1878-0296

Carrer, P., Kotzias, D., Rameckers, E., Seppanen, O., van Bronswijk, J. \& Viegi, G. (2002). THADE project - Towards healthy air in dwellings in Europe. European Federation of Allergy and Airways Disease Patients and Associations

Chow, J.C. \& Watson, J.G. (1999). In: Landsberger, S. \& Creactchman, M. (Eds.), Elemental Analysis of Airborne Particles. Advances in Environmental, Industrial and Process Control Technologies, Vol.1 Gordon and Breach Sciences Publishers, USA, pp. 97-137, ISBN 9056996274

Daisey, J.M., Angell, W.J. \& Apte, M.G. (2003). Indoor air quality, ventilation and health symptoms in schools: an analysis of existing information. Indoor Air, Vol.13, No.1, pp.53-64, ISSN 1600-0668

Dales, R., Liu, L., Wheeler, A.J. \& Gilbert, N. (2008). Quality of indoor residential air and health. Canadian Medical Association Journal, Vol.179, No.2, pp. 147-152, ISSN 14882329

Diário da República, Decreto-Lei n. $79 / 2006$, de 4 de Abril. Available from <http://dre.pt/pdf1sdip/2006/04/067A00/24162468.pdf>.

Estoková, A., Stevulová, N. \& Kubincová, L. (2010). Particulate matter investigation in indoor environment. Global Nest Journal, Vol.12, No.1, pp. 20-26.

Fang, G., Wu, Y., Chang, S., Huang, S. \& Rau, J. (2006). Size distributions of ambient air particles and enrichment factor analyses of metallic elements at Taichung Harbor near the Taiwan Strait. Atmospheric Research, Vol.81, No.4, pp. 320-333, ISSN 01698095

Fraga, S., Ramos, E., Martins, A., Samúdio, M. J., Silva, G., Guedes, J., Fernandes, E. O. \& Barros, H. (2008). Indoor air quality and respiratory symptoms in Porto schools. Revista Portuguesa de Pneumologia, Vol.14, No.4, pp. 487-507, ISSN 0873-2159 
Franck, U., Herbarth, O., Roder, S., Schlink, U., Borte, M., Diez, U.,Krämer, U. \& Lehmann, I. (2011). Respiratory effects of indoor particles in young children are size dependent. Science of the Total Environment, Vol.409, No.9, pp. 1621-1631, ISSN 0048-9697

Fromme, H., Twardella, D., Dietrich, S., Heitmann, D., Schierl, R., Liebl, B. \& Rüden, H. (2007). Particulate matter in the indoor air of classrooms-exploratory results from Munich and surrounding area. Atmospheric Environment, Vol.41, No.4, pp. 854-866, ISSN 1352-2310

Gilli, G., Traversi, D., Rovere, R., Pignata, C. \& Schilirò, T. (2007). Airborne particulate matter: Ionic species role in different Italian sites. Environmental Research, Vol.103, No.1, pp. 1-8, ISSN 0013-9351

Godoi, R.H.M., Avigo, D.J., Campos, V.P, Tavares, T.M., Marchi, M.R.R., Grieken, R. \& Godoi, A.F.L. (2009). Indoor air quality assessment of elementary schools in Curitiba, Brazil. Water, Air, Soil Pollution: Focus, Vol.9, No.3-4, pp. 171-177, ISSN 1573-2940

Godwin, C., \& Batterman, S. (2007). Indoor air quality in Michigan schools. Indoor Air, Vol.17, No. 2, pp. 109-121, ISSN 1600-0668

González-Flecha, B. (2004). Oxidant mechanisms in response to ambient air particles. Molecular Aspects of Medicine, Vol.25, No.1 and 2, pp. 169-182, ISSN 0098-2997

Goyal, R. G. \& Khare, M. (2009). Indoor-outdoor concentrations of RSPM in classroom of a naturally ventilated school building near an urban traffic roadway. Atmospheric Environment, Vol.43, No.38, pp. 6026-6038, ISSN 1352-2310

Grigg, J. (2009). Particulate Matter Exposure in Children. Proceedings of American Thoracic Society, Vol.6, No.7, pp. 564-569, ISSN 1546-3222

Guo, H., Lee, S.C., Chan, L.Y. \& Li, W.M. (2004). Risk assessment of exposure to volatile organic compounds in different indoor environments. Environmental Research, Vol.94, No.1, pp. 57-66, ISSN 0013-9351

Health Effects Institute (2002). HEI Perspectives, available from $<$ http:// pubs.healtheffects.org/getfile.php?u=244>

Hodgson, M. (1992). Field studies on the sick building syndrome. Annals of the New York Academy of Sciences, Vol.641, pp.21-36, ISSN 0077-8923

Hollander, M. \& Wolfe, D.A. (1973). Nonparametric statistical methods. John Wiley \& Sons.

Hwang, B., Jaakkola, J. J., Lee, Y., Lin, Y. \& Guo, Y. (2006). Relation between air pollution and allergic rhinitis in Taiwanese schoolchildren. Respiratory Research, Vol.7, No.1, pp. 1-7, ISSN 1465-9921

ISAAC (1998). Worldwide variation in prevalence of symptoms of asthma, allergic rhinoconjunctivitis, and atopic eczema: ISAAC. The Lancet, Vol.351, No.9111, pp. 1225-1232, ISSN 0140-6736

Janssen, N. A., Hoek, G., Brunekreef, B. \& Harssema, H. (1999). Mass concentration and elemental composition of PM10 in classrooms. Occupational Environmental Medicine, Vol.52, No.7, pp. 482-487, ISSN 1470-7926

Janssen, N., van Vliet, N., Aaarts, F., Harssema, H. \& Brunekreef, B. (2001). Assessment of exposure to traffic related air pollution of children. Atmospheric Environment, Vol.35, No.22, pp. 3875-3884, ISSN 1352-2310 
Jenkins, P. L., Phillips, T. J. \& Mulberg, E. J. (1992). Activity patterns of californians : use of and proximity to indoor pollutants sources. Atmospheric Environment. Vol.26, No.12, pp.2141-2148, ISSN 1352-2310

Karthikeyan, S. \& Balasubramanian, R. (2006). Determination of water-soluble inorganic and organic species in atmospheric fine particulate matter. Microchemical Journal, Vol.82, No.1, pp. 49-55, ISSN 1095-9149

Khan, I., Freitas, M. C., Dionísio, I. \& Pacheco, A.M.G. (2007). Indoor habits of children aged 5 to years learning at the public basic schools of Lisbon city, Portugal. Proceedings of the Ninth REHVA World Congress Clima - Well Being Indoors, ISBN 978-952-99898-2-9

Kim, J., Elfman, L., Wieslander, G., Smedje, G. \& Norback, D. (2007). Indoor molds, bacteria, microbial volatile organic compounds and plasticizers in schools - associations with asthma and respiratory symptoms in pupils. Indoor Air, Vol.17, No.2, pp. 153163, ISSN 1600-0668

Kosonen, R. \& Tan, F. (2004). The Effect of Perceived Indoor Air Quality on Productivity Loss. Energy and Buildings, Vol.36, No.10, pp. 981-986, ISSN 0378-7788

Lee, S.C., Ho, K.F., Chan, L.Y., Zielinska, B. \& Chow, J.C. (2001). Polycyclic aromatic hydrocarbons (PAHs) and carbonyl compound in urban atmosphere of Hong Kong. Atmospheric Environment, Vol.35, No.34, pp. 5949-5960, ISSN 1352-2310

Lee, S.C., Li, W.M. \& Ao, C.H. (2002). Investigation of indoor air quality at residential homes in Hong Kong-case study. Atmospheric Environment, Vol.36, No.2, pp. 225-237, ISSN 1352-2310

Lee, S.C., Guo, H., Li, W.M. \& Chan, L.Y. (2002). Inter comparison of air pollutant concentrations in different indoor environment in Hong Kong. Atmospheric Environment, Vol.36, No.12, pp. 1929-1940, ISSN 1352-2310

Li, W.M., Lee, S.C. \& Chan, L.Y. (2001). Indoor air quality at nine shopping malls in Hong Kong. Science of the Total Environment, Vol.273, No.1-3, pp. 27-40, ISSN 0048-9697

Lunden, M. M., Revzan, K.L., Fischer, M.L., Thatcher, T.L., Littlejohn, D., Hering, S. V. \& Brown, N. J. (2003). The transformation of outdoor ammonium nitrate aerosols in the indoor environment. Atmospheric Environment. Vol.37, pp. 5633-5644, ISSN 13522310

Mendell, M. \& Heath, G. (2005). Do indoor pollutants and thermal conditions in schools influence student performance? A critical review of the literature. Indoor Air, Vol.15, No.1, pp. 27-52, ISSN 1600-0668

Mysliwiec, M.J. \& Kleeman, M.J. (2002). Source apportionment of secondary airborne particulate matter in a polluted atmospheric. Environmental Science \& Technology, Vol.36, No.24, pp. 5376-5384, ISSN 0013-936X

Norback, D., Bjornsson, E., Janson, C. \& Boman, G. (1995). Asthmatic symptoms and volatile organic compounds, formaldehyde and carbon dioxide in dwellings. Occupational and Environmental Medicine, Vol.52, No.6, pp. 388-395, ISSN 1470-7926

Pegas, P.N.; Evtyugina, M.G.; Alves, C.A.; Nunes, T.; Cerqueira, M.; Franchi, M. \& Pio, C.A. (2010). Outdoor/Indoor air quality in primary schools in Lisbon: a preliminary study. Química Nova, Vol.33, No.5, pp. 1145-1149, ISSN 1678-7064

Pegas, P.N.; Alves, C.A.; Evtyugina, M.G.; Nunes, T.; Cerqueira, M.; Franchi, M.; Pio, C.A.; Almeida, S.M.; Cabo Verde, S. \& Freitas, M.C. (2011a). Seasonal evaluation of 
outdoor/indoor air quality in primary schools in Lisbon. Journal of Environmental Monitoring, Vol. 13, pp. 657-667, ISSN 1464-0333

Pegas, P.N.; Alves, C.A.; Evtyugina, M.G.; Nunes, T.; Cerqueira, M.; Franchi, M.; Pio, C.A.; Almeida, S.M. \& Freitas, M.C. (2011b). Indoor air quality in elementary schools of Lisbon in spring. Environmental Geochemistry and Health, ISSN 1573-2983 (in press; doi:10.1007/s10653-010-9345-3).

Ramachandran, G., Adgate, J. L., Banerjee, S., Church, T. R., Jones, D., Fredrickson, A. \& Sextond, K. (2005). Indoor air quality in two urban elementary schools measurements of airborne fungi, carpet allergens, $\mathrm{CO}_{2}$, temperature and relative humidity. Journal of Occupational and Environmental Hygienne, Vol.2, No.1, pp. 553566, ISSN 1545-9632

Saliba, N. A., Atallah, M. \& Al-Kadamany, G. (2009). Levels and indoor-outdoor relatioship of PM10, and soluble inorganic ions in Beirut, Lebanon. Atmospheric Research, Vol.92, No.1, 131-137, ISSN 0169-8095

Schlesinger, R. B., \& Cassee, F. (2003). Atmospheric secondary inorganic particulate matter: the toxicological perspective as a basics for health effects risk assessment. Inhalation Toxicology, Vol.15, No.3, pp. 197-235, ISSN 1091-7691

Spangler, J. D., \& Sexton, K. (1983). Indoor air pollution: A public health perspective. Science, Vol.221, No.4605, pp.9-17, ISSN 1095-9203

Stranger, M., Potgieter-Vermaak, S. \& Van Grieken, R. (2007a). Comparative overview of indoor air quality in Antwerp, Belgium. Environment International, Vol.33, No.6, pp. 789-797, ISSN 0160-4120

Stranger, M., Potgieter-Vermaak, S. \& Van Grieken, R. (2007b). Characterization of indoor air quality in primary schools in Antwerp, Belgium. Indoor Air, Vol.18, No.6, pp. 454-463, ISSN 1600-0668

Tippayawong, N., Khuntong, P., Nitatwichit, C., Khunatorn, Y. \& Tantakitti, C. (2009). Indoor/outdoor relationships of size-resolved particle concentrations in naturally ventilated school environments. Building and Environment, Vol.44, No.1, pp. 188197, ISSN 0360-1323

Unites States Environmental Protection Agency (EPA). (2010). Managing Asthma in the School Environment - Indoor air quality tools for schools, available from <http://www.epa.gov/iaq/schools>.

Wilson, R., \& Spengler, J. (1996). Particles in Our Air: Concentrations and Health Effects. Boston, Vol.25, ISBN: 978-0674240773

Wheeler, L., Buckley, R., Gerald, L. B., Merkle, S. \& Morrison, T. A. (2009). Working with schools to improve pediatric asthma management. Pediatric Asthma, Allergy \& Immunology, Vol.22, No.4, pp. 197-207, ISSN 08831874

Wolkoff, P. (1999). How to measure and evaluate volatile organic compound emissions from building products. A perspective. The Science of the Total Environment, Vol.227, No.23, pp. 197-213, ISSN 0048-9697

Wolkoff, P., Schneider, T., Kildeso, J., Degerth, R., Jaroszewski, M. \& Schunk, H. (1998). Risk in cleaning: chemical and physical exposure. The Science of the Total Environment, Vol.215, No. 1-2, pp. 135-156, ISSN 0048-9697 
World Health Organization. (n.d.). Children aged 0-4 years living in households using biomass fuels or coal as the main source of heating and cooking, available from <http://www.who.int/ceh/indicators/0_4biomassfuels.pdf>.

World Health Organization (WHO) (2010), Guidelines for indoor air quality - selected pollutants. Denmark, ISBN 9789289002134.

Viegas, S. \& Prista, J. (2010). Formaldehyde in Indoor Air: A Public Health Problem?. WIT Transactions on Ecology and the Environment, Vol. 136, ISSN 1743- 